\title{
Simulating impacts of EFR consideration on reservoir operation policy and irrigation management in the Hari Rod River Basin, Afghanistan
}

\author{
S.K. Adhikary ${ }^{a}, \underline{\text { S.K. Das }}{ }^{b}$, S.S. Atef ${ }^{c}$, A. DasGupta ${ }^{d}$ and M.S. Babel ${ }^{d}$ \\ ${ }^{a}$ Department of Civil Engineering, Khulna University of Engineering \& Technology (KUET), Bangladesh \\ ${ }^{b}$ School of Engineering and Science, Victoria University, Melbourne 14428, Australia \\ ${ }^{c}$ Chief Executive \& Consultant, ULTRA DESIGN Research \& Consulting Company, Afghanistan \\ ${ }^{d}$ Water Engineering and Management Field of Study (FoS), Asian Institute of Technology (AIT), Thailand \\ Email: sushilkumar.das@live.vu.edu.au
}

\begin{abstract}
The concept of the river environmental flow requirement (EFR) is emerged from the necessity of establishing a certain water level in the river to which the flow regime of the river can be altered from natural condition while preserving sustainability of the riverine ecosystem (Song et al., 2007; Tharme, 2003). There exists an unbalanced ecological environment in the Hari Rod River basin in Afghanistan, where the natural flora and fauna have been affected due to the years of civil war, severe drought, and growing pressure on the available water resources by different sectors. Sustainable utilization and effective allocation of the water resource while preserving integrity in the riverine ecosystem require understanding of the river flow systems in all river basins of Afghanistan. Thus, the present study attempts to quantify EFR required for healthy ecosystem, and potential impacts on the reservoir (proposed Salma dam reservoir) operation policy as well as irrigation management due to EFR allocation in the Hari Rod River basin of Afghanistan.
\end{abstract}

The methodology followed in this study is largely based on observed data and information in the field. Recent (2001-2008) and past (1961-1980) records of available daily discharge and river bathymetry surveyed data are collected from Tagab Gaza monitoring station in the Hari Rod River. The secondary hydrological data is collected from irrigation department and FAO-EIRP office in Herat city of Afghanistan, and primary data is taken directly from field. The Tagab Gaza station is located immediately downstream of the reservoir and thus, EFR is estimated in this station to be applied in reservoir simulation model. Mean monthly precipitation, temperature, evaporation and soil data for the whole basin are also collected to calculate irrigation water requirement (IWR) for reservoir simulation. The methodological framework is divided into two parts: estimation of EFR and potential impacts of allocating EFR on reservoir operation policy and irrigation management by applying simulation technique. Well-known hydrological methods: (e.g. Tessman, Flow Duration Curve, 7Q10, Indicators of Hydrologic Alteration) and hydraulic method (e.g. Wetted Perimeter) were applied to quantify EFR. Details of all these approaches can be found in (Smakhtin and Anputhas, 2006). Two public domain models, HEC-ResSim and CROPWAT were used as tools to simulate reservoir system and to calculate IWR respectively.

The result shows that hydrological based approaches are appropriate to estimate EFR in the Hari Rod River basin of Afghanistan. Generally, there is an indirect effect of allocating EFR on other existing demands from different sectors. Based on this assumption, reservoir model is simulated to operate the proposed reservoir (Salma dam) in the Hari Rod River basin of Afghanistan. Different alternative scenarios based on with or without EFR following existing or proposed guide curve, were generated to evaluate the possible impacts of EFR consideration on reservoir operation policy as well as on other (i.e. irrigation and hydropower) demands. Different mitigation options were also developed to minimize the impacts. Using simulation technique, a new conservation rule curve is developed to decrease the water shortages for irrigation caused by the additional demand due to EFR allocation. The present study conclusively proves that only $5 \%$ improvement in irrigation efficiency (IE) can mitigate entire water shortage impact in the Hari Rod River basin of Afghanistan.

Keywords: Environmental flow requirement (EFR), HEC-ResSim and CROPWAT, Irrigation efficiency, Salma dam reservoir, Hari Rod River basin 
Adhikary et al., Simulating Impacts of EFR Consideration on Reservoir Operation Policy and Irrigation Management in the Hari Rod River basin, Afghanistan

\section{INTRODUCTION}

Worldwide increasing concerns over environmental sustainability and preserving ecosystems and their associated functions in rivers persuade the water managers to recognize the requirement of allocating specific amount of flow in the rivers with an acceptable level of quality which is often regarded as environmental flow requirement (EFR) (Tharme, 2003). EFR is the amount of water in the original river flow regime that needs to flow all the way along its course in order to maintain the specified valued features of the river ecosystem in a desirable condition (Smakhtin et al., 2004; Song et al., 2007). Through mimicking the natural flow regime, EFR ensures the provisions of ecosystem goods and services that rivers provide on which humanity rely in numerous ways. Therefore, such flow is recommended in all the regulated rivers across the world to preserve ecosystems integrity to a certain desired level.

Hari Rod River basin in Afghanistan has unstable environment where the ecological flora and fauna have been affected due to the years of civil war, severe drought, growing pressure on available water by irrigation sector within the catchments, and lack of attention to environmental impacts. The primary focus of water resources development projects in Afghanistan particularly in the Hari Rod River basin are irrigation and hydropower. Until now, less attention was paid on low flow and EFR downstream of these developments. However, with increasing consciousness and approbation for maintaining environmental sustainability, the apprehension to minimize adverse environmental impacts of such plans is getting much more attention nowadays. Legislation in Afghanistan emphasizes that its water resources management plan should reserve satisfactory amount of water to be required for environmental purposes in all its river basins. It is also highlighted in the water sector strategy of the country's national development plan. However, little is known about the existing environmental and natural circumstances of the river basins in Afghanistan except few reports identifying the possible management plans and development options (Qureshi, 2002). This has led to the recognition that environmental flow (EF) in each of the river basins in Afghanistan along with the potential impacts need to be quantified.

The available discharge in the Hari Rod River, which is mainly used for irrigation purpose within the basin, is deficit during the summer and excess in the spring. Accordingly, water user groups in the basin have adjusted their agricultural and irrigation water supplies to natural flow regime available in the river. However, there is a lack of distribution efficiency in the major sub-branches of the river caused by corrupted canal diversions, alignments and devastated bifurcations (Qureshi, 2002). Considering the present state of water management, establishment of environmental water requirement for the river is regarded as an essential part prior to any water resources development projects in the Hari Rod River basin of Afghanistan. The primary intention of EF management in the basin must be the anticipation of further degradation that may arise from flow regulation intensification, particularly loss of high flood flows, reduced base flows and further alteration in the seasonal inflows. Aiming to contribute to the research gap, this paper attempts to assess the EFR of the Hari Rod River in Afghanistan as well as the potential impacts of integrating EFR into reservoir operation policy and irrigation management in the Hari Rod River basin of Afghanistan.

\section{THE HARI ROD RIVER BASIN}

Hari Rod River basin is located in western part of Afghanistan (Figure 1), which is relatively more developed than other basins in that area of the country. Upper part of the basin is located in the Ghor province with an altitude of $4000 \mathrm{~m}$ above mean sea level (MSL), and lower part is in the Herat province having an altitude of $750 \mathrm{~m}$ above MSL. The basin area covers about 3.9 Mha with 0.46 million population. Hari Rod River has narrow valley with gravelly bed in the upper reach, and in the middle reach the river valley becomes wide, flat and meanders greatly below the village Obeh. In the lower reaches, the river forms part of the international boundary between Afghanistan and Iran, and finally flow into Turkmenistan where it disappears into the sand in downstream. The basin is characterized by

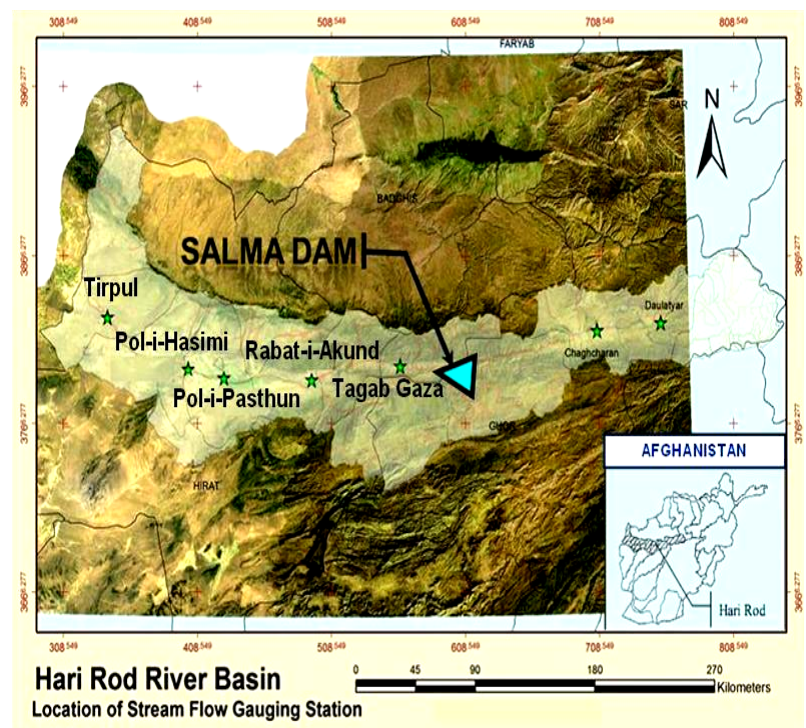

Figure 1. The Hari Rod River basin in Afghanistan. 
Adhikary et al., Simulating Impacts of EFR Consideration on Reservoir Operation Policy and Irrigation Management in the Hari Rod River basin, Afghanistan

distinguished climate with cold winters with snowfall, and spring with rainfall increasing with rising altitude. The mean annual precipitation is $236 \mathrm{~mm}$ with uneven spatial distribution. Runoff comes from snowmelt, which is the major source of surface water and groundwater of the basin spanning over only two months (February/March to April). High flood flows from March to June, and very low flows from August to February are observed in the Hari Rod River. Discharge from the river is mainly used for irrigation purposes, and farmers have adapted their agricultural activities to this flow regime. In addition, groundwater is used as a supplement to satisfy the irrigation demand throughout the year. Salma dam reservoir is located near the Chisht-e-Sharif in Herat province, which is planned as a multi-purpose reservoir to support the irrigation activities and power generation. Now the project is under active construction that is to be utilized in the upcoming years. The reservoir should meet the current irrigation demand of 42000 ha, and generate an installed capacity of $42 \mathrm{MW}$ early after construction, and expected to meet the future irrigation demand for 74859 ha after development of irrigation facilities. Considering the present status of demand and reservoir storage, no shortage is observed for irrigation when reservoir is operating only for hydropower generation. Even EFR is satisfied in this base condition. Thus, the present study attempts to evaluate the future impact when irrigation demand is expected to be very high, and reservoir will be operated in the interest of both irrigation and hydropower demand along with EFR demand.

\section{MATERIALS AND METHODS}

\subsection{Estimation of EFR for the Hari Rod}

The framework of methodology (Figure 2) mainly consists of two subsets of activities: quantifying EFR and establishing reservoir operation policy applying simulation technique to mitigate the impacts of incorporating EFR on other demands. The methodology followed in this study is largely based on observed data and information in the field. Recent (2001-2008) and past (1961-1980) available daily discharge, and river cross-section data at Tagab Gaza monitoring station (located immediately downstream of the reservoir) in the Hari Rod river were collected. However, there has not been any observation made during 1981 to 2000 due to several years of conflict. The primary hydrological data (river cross-section) is collected from the field survey at different points of the Hari Rod River and the secondary hydrological data is taken from irrigation department and FAO-EIRP office in Herat city

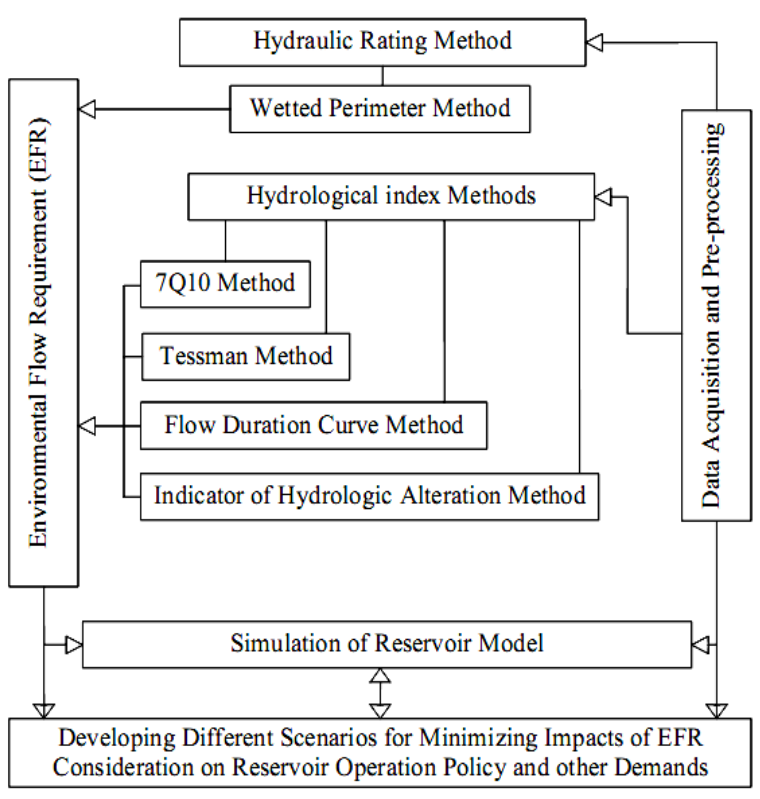

Figure 2. The methodological framework used in study. of Afghanistan. Simple approaches have been adopted to analyze the available hydrological data. Wellknown hydrological methods: (e.g. Tessman, Flow Duration Curve, 7Q10, Indicators of Hydrologic Alteration) and hydraulic method (e.g. Wetted Perimeter) were applied to quantify EFR in this study. Smakhtin and Anputhas (2006) provide a detail review of all these approaches to estimate EFR.

\subsection{Simulation of the Reservoir System}

HEC-ResSim, a public domain model for reservoir system simulation by USACE, is used for simulating the reservoir (proposed Salma dam reservoir) operation in the Hari Rod river basin. It utilizes reservoir inflow hydrographs, river networks, and physical properties of the dam including reservoir characteristics and rule curves as necessary input data. Reservoir release, storage, spillway flow and downstream hydrographs are the model output. In the developed reservoir model, water is firstly allocated only for irrigation and hydropower demand, and then EFR demand is considered along with them in sequence on a priority basis. Twenty years daily time series data is used as input in the reservoir model during simulation. Another public domain model CROPWAT (FAO, 1999) is used to estimate the irrigation water requirement (IWR) for each crop of Herat province located downstream of reservoir. Mean monthly temperature, rainfall, evaporation and soil data are used to estimate net irrigation depth for each crop. Finally, three different scenarios are generated to evaluate the potential impacts of allocating EFR on irrigation and hydropower demand, and possible solutions are suggested to mitigate those impacts in the Hari Rod basin of Afghanistan. 
Adhikary et al., Simulating Impacts of EFR Consideration on Reservoir Operation Policy and Irrigation Management in the Hari Rod River basin, Afghanistan

\section{RESULTS}

\subsection{EFR for the Hari Rod River}

Major tributaries are located in the lower part of the Hari Rod River basin. Thus, the present study considered the monitoring stations located in the lower part of the basin for EFR assessment. Tagab Gaza and Tirpul station is located in the middle and lower part of the basin respectively along with three more gauging stations (Pol-i-Pashtun, Pol-i-Hashimi and Rabat-i-Akhund) along the river between these two stations (Figure 1). Since the Tagab Gaza monitoring station is located immediately downstream of the reservoir, EFR estimation in that station is more justified to be incorporated into the reservoir simulation. Estimated EFR in Tagab Gaza is presented in Table 1.

Table 1: Estimated EFR $\left(\mathrm{m}^{3} / \mathrm{s}\right)$ in Tagab Gaza monitoring station using different well-known methods

\begin{tabular}{lcccccccccccc}
\hline Methods & Jan & Feb & Mar & Apr & May & Jun & Jul & Aug & Sep & Oct & Nov & Dec \\
\hline Tessman & 7.90 & 9.20 & 15.70 & 15.90 & 15.90 & 15.90 & 14.00 & 7.70 & 7.40 & 7.10 & 7.60 & 7.60 \\
FDC90 & 9.64 & 9.64 & 9.64 & 9.64 & 9.64 & 9.64 & 9.64 & 9.64 & 9.64 & 9.64 & 9.64 & 9.64 \\
7Q10 & 5.10 & 5.10 & 5.10 & 5.10 & 5.10 & 5.10 & 5.10 & 5.10 & 5.10 & 5.10 & 5.10 & 5.10 \\
IHA & 4.68 & 5.02 & 6.29 & 11.10 & 19.90 & 19.90 & 10.50 & 6.24 & 6.06 & 6.42 & 5.53 & 5.51 \\
WP & 7.71 & 7.71 & 7.71 & 7.71 & 7.71 & 7.71 & 7.71 & 7.71 & 7.71 & 7.71 & 7.71 & 7.71 \\
\hline
\end{tabular}

Note: $\mathrm{FDC}=$ Flow duration curve; $\mathrm{IHA}=$ Indicators of hydrologic alteration; $\mathrm{WP}=\mathrm{Wetted}$ perimeter

Tessman (modified Tennant) method uses a percentage of the average annual flow (AAF) for a monthly basis rather than two season (six months period) basis (Tennant method) to estimate EFR, which refers that this method considers seasonal variability. For selecting monthly minimum flow (MMF), this method applies the criteria such as: if average monthly flows (AMF) $<40 \%$ of average annual flow (AAF), then MMF equals the $\mathrm{AMF}$, if $\mathrm{AMF}>40 \%$ of $\mathrm{AAF}$, then MMF equals $40 \%$ of $\mathrm{AAF}$, and if $40 \%$ of $\mathrm{AMF}>40 \%$ of $\mathrm{AAF}$, then MMF equals $40 \%$ of AAF respectively. In FDC method, generally $\mathrm{Q}_{95}$ and $\mathrm{Q}_{90}$ index are used to define EFR, which indicate the extreme low flow conditions to protect the riverine ecosystem integrity. 7-day low flow with a 10-year return period is calculated to quantify EFR in 7Q10 method using 20 years daily discharge data. This method depicts that the resulted minimum stream flow should be maintained to protect river water quality. IHA method quantifies the hydrologic sequential variability of flow regime into 32 biological parameters based on statistical evaluation. These parameters were calculated from 20 years daily records (1961 to 1980) at Tagab Gaza station by considering single period analysis with nonparametric statistics using IHA (Indicators of Hydrologic Alteration) software released by Nature conservancy, USA. The result shows that there is an alteration between the recent (1971-1980) and pre-settlement (1962-1970) period. The monthly low flow median in pre-impact period is $6.4 \mathrm{~m}^{3} / \mathrm{s}$, which is decreased to $5.3 \mathrm{~m}^{3} / \mathrm{s}$ in post-impact period. There is significant variation in April and May median flows of post-impact period compared to preimpact period. The results from IHA analysis are used for Range of Variability Approach (RVA), and the management targets are identified. First, the management rules are developed based on the estimated ecological information needed to accomplish the target flows on annual basis. Then, biological goals are identified to achieve through generated flow regime. The nonparametric monthly low flow analysis for Tagab Gaza station indicate that the post-impact period peak discharge and volume increased by $4 \%$ compared to pre-impact period. The positive and negative changes in water conditions are increased from pre-impacted period to post-impact period. In the wetted perimeter method, the estimated EFR is $7.71 \mathrm{~m}^{3} / \mathrm{s}$. Since it is difficult to estimate the point of maximum curvature in the wetted perimeter to discharge relationship, EFR is obtained based on the breaks in slope of wetted perimeter verses discharge diagram.

Tessman methods generally provide good results at initial level of analysis. However, most often it gives unexpected under or over estimated results due to seasonal condition. EFR by this method is considerably higher than other methods in dry season. EFR by 7Q10, wetted perimeter and FDC approach are lower than that by Tessman method. FDC method concise the entire flow distribution, and shows the range of extreme low flow conditions, and can be used for primary screening of the complete series of river discharge from low flow to flood events. However, when the question of seasonal variability arises, 7Q10, FDC and wetted perimeter method cannot fully include EFR in the management level. It is recognized that intra and interannual variability of hydrologic regimes are needed to maintain and restore the natural forms and functions of the aquatic ecosystems. Thus, IHA considering RVA is the most sophisticated form of hydrological index approaches to quantify EFR in a basin. It generally considers the magnitude, duration and frequency of flow regime. Therefore, the estimated EFR using IHA method is incorporated into reservoir simulation model to define its EFR demand during simulation of the reservoir and evaluating the impacts of EFR on other existing demands. 
Adhikary et al., Simulating Impacts of EFR Consideration on Reservoir Operation Policy and Irrigation Management in the Hari Rod River basin, Afghanistan

\subsection{Scenario-based Simulation of the Reservoir (Proposed Salma Dam) System}

\section{Scenario I: Simulation of Reservoir System without Considering EFR}

The intention of developing this scenario at base condition is to elaborate the dam status immediately after construction as the reservoir is being designed to operate for both irrigation and hydropower demand. The simulation shows that there are about 18 fully satisfied years for irrigation within 20 years of analysis. The irrigation shortage is observed in only two dry years in specific months of dry season. Available water in the reservoir is very less in the year 1966 and from 1970 to 1971. Thus, these two periods are highlighted in this study. The irrigation shortage from August to November in 1971 is presented in Figure 3, and in that year total annual inflow is $281 \mathrm{Mm}^{3}$. However, the average annual irrigation demand and average annual inflow (AAI) to the river is found as $584 \mathrm{Mm}^{3}$ and $1,217 \mathrm{Mm}^{3}$ respectively. This implies that there is no shortage for irrigation for normal and wet years, if the reservoir inflow is equal or more than the estimated AAI. The result also shows that total reservoir inflow in year 1969 to 1970 was almost same as in year 1971, but there was no shortage observed. This is due to the reservoir storage during 1968 to 1969 period when reservoir inflow is more than the estimated average inflow. Thus, besides meeting the demands, much water was stored in the reservoir and released in the year 1970, and no shortage was observed in that specific year. Observation shows that annual inflow in 1971 was extremely low which is almost equal to one-fifth of AAI. Although there was less inflow to the reservoir, simulation shows that a total of 8 months (Jan. to end of Jul.) was fully satisfied. However, irrigation demand was satisfied $20 \%$ in Aug., and $45 \%$ in Sep. and Oct., assuming that there is no irrigation demand on Dec. The average energy simulated is reasonably more than the proposed capacity $(186.13 \mathrm{MWh})$. This is because the release for both hydropower and irrigation is from hydropower gate in order to optimize both demands. It is considered as a key reference to compare with other scenarios.

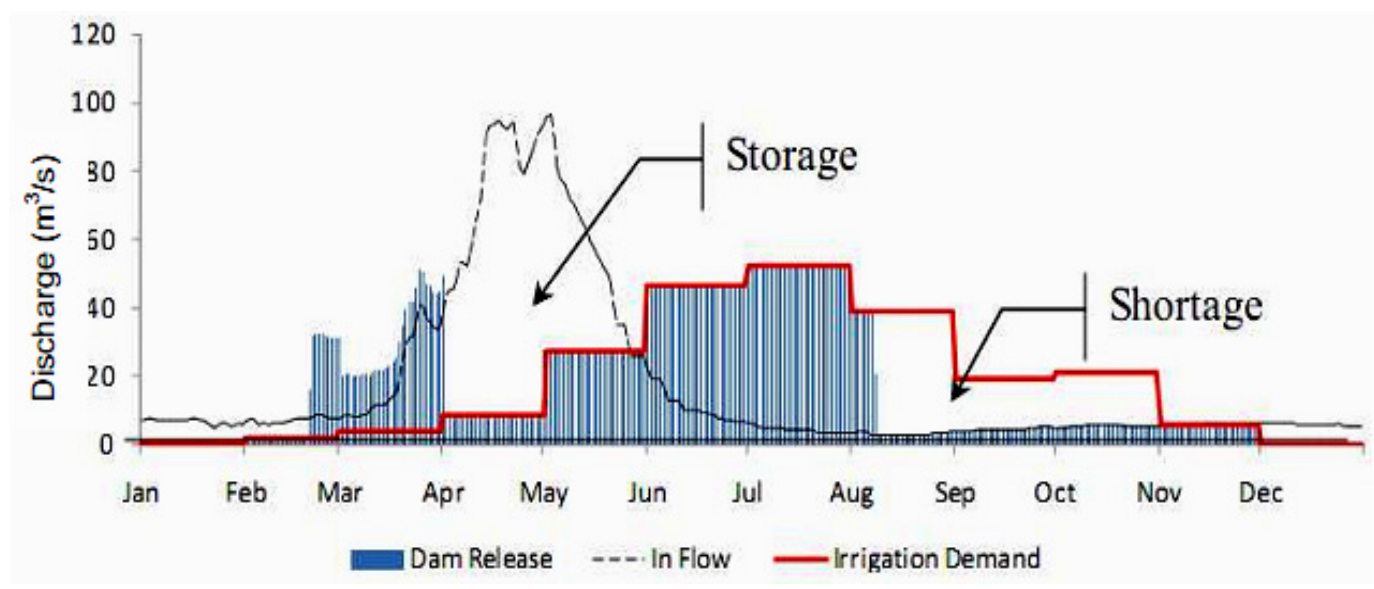

Figure 3. Dam release without considering EFR to satisfy irrigation demand in 1971.

\section{Scenario II: Simulation of Reservoir System by Considering EFR}

This scenario evaluates the impacts of incorporating the EFR into reservoir operation policy on the other existing demands. The simulation shows that there will be more stress on irrigation demand in the specific dry years (Figure 4). The release decision to satisfy EFR was defined as a minimum reservoir supply on monthly basis. This decision is made in reservoir hydropower gate, and then EFR is evaluated downstream of the river at Tirpul station (Figure 1). River routing is carried out to calibrate the estimated EFR downstream of the river. Table 2 presents the impacts of EFR consideration into reservoir operation policy on irrigation demand. The shortage is observed from Aug. to Oct. of 1966, 1970 and 1971 out of 19 years of simulation. In addition, severe shortage is noticed in 1971, where reservoir is meeting almost $22 \%$ of the irrigation demand. However, much difference is not observed in average energy produced after adding EFR demand in reservoir simulation model.

Table 2: Shortage to satisfy irrigation demand due to EFR consideration for scenario II

\begin{tabular}{lcccccccc}
\hline Description & Aug-66 & Sep-66 & Oct-66 & Sep-70 & Oct-70 & Aug-71 & Sep-71 & Oct-71 \\
\hline Release $\left(\mathrm{Mm}^{3}\right)$ & 59.0 & 14.2 & 16.5 & 37.7 & 19.2 & 24.3 & 10.9 & 13.9 \\
Irrig. Demand $\left(\mathrm{Mm}^{3}\right)$ & 101.0 & 49.8 & 54.8 & 49.8 & 54.8 & 101.0 & 49.8 & 54.8 \\
\% Satisfied & 58 & 29 & 30 & 76 & 35 & 24 & 22 & 25 \\
\hline
\end{tabular}


Adhikary et al., Simulating Impacts of EFR Consideration on Reservoir Operation Policy and Irrigation Management in the Hari Rod River basin, Afghanistan

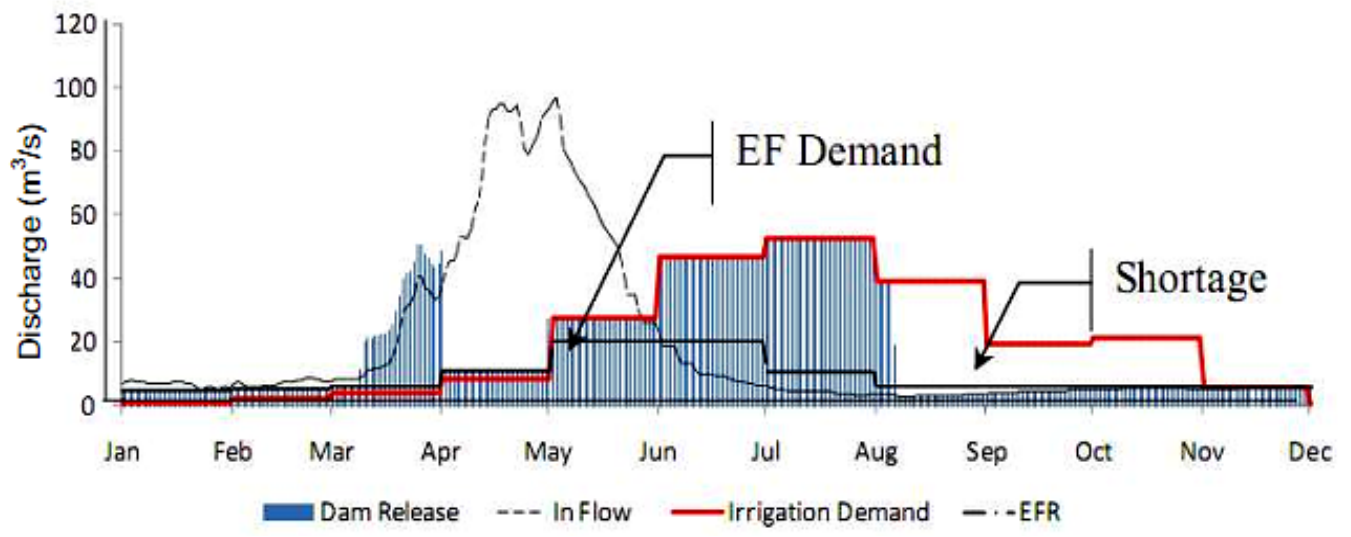

Figure 4. Shortage of irrigation demand in 1971 by considering EFR into reservoir operation.

\section{Scenario III: Developing Proposed Guide Curve for Reservoir Operation}

The simulation shows that reservoir starts to storing water from Apr. to end of Jun., and releases from Jul. to next Apr. This release decision is applicable in normal and wet years, where the dam inflow is almost equal to AAI. It may also help to decrease the possibility of flooding while meeting irrigation demand and generating energy. However, during drought period, when the dam inflow is almost one-fifth of AAI, the existing conservation zone will not fully meet the irrigation, hydropower and EFR demands. Thus, a new conservation zone is developed based on dry year circumstances to meet all three demands during dry years. The result also shows that no shortage will be observed after applying the new rule curve (Figure 5) of conservation zone. Results obtained by all the scenarios are summarized to evaluate the impacts of EFR consideration on the irrigation and hydropower demand (Table 3). It shows that when reservoir releases for only irrigation and hydropower, there is shortage for years 1966 and 1971 . However, after EFR inclusion into the reservoir operation policy along with other demands, shortage is noticed for the years 1966, 1970 and 1971. Afterwards, by applying the proposed new conservation rule estimated in scenario III, it can be shown that there is no shortage for irrigation, hydropower and EFR demand. At the same time, the energy generated in those specific years (1966 and 1971) for scenario III is more then that for scenarios I and II respectively.

Table 3: Comparison of the results obtained by all three scenarios

\begin{tabular}{|c|c|c|c|c|c|c|c|c|}
\hline \multirow{2}{*}{$\begin{array}{l}\text { Description } \\
\text { Irrigation }\end{array}$} & \multirow{2}{*}{$\frac{\text { Unit }}{\text { Years }}$} & \multicolumn{2}{|c|}{$\begin{array}{c}\text { Irrig.+Pwr/Exist. Cons. } \\
\text { Zone (Scenario I) } \\
\end{array}$} & \multicolumn{3}{|c|}{$\begin{array}{c}\text { Irrig.+Pwr+EFR/Exist. Cons. } \\
\text { Zone (Scenario II) } \\
\end{array}$} & \multicolumn{2}{|c|}{$\begin{array}{c}\text { Irrig.+Pwr+EFR/New Cons. } \\
\text { Zone (Scenario III) }\end{array}$} \\
\hline & & 1966 & 1971 & 1966 & 1970 & 1971 & 1966 & 1971 \\
\hline \multirow[t]{2}{*}{ Shortage } & $\mathrm{Mm}^{3}$ & 114 & 155 & 116 & 86 & 157 & 0 & 0 \\
\hline & $\%$ & 54 & 73 & 56 & 54 & 76 & 0 & 0 \\
\hline Power Gen. & MWh & 154.5 & 121.6 & 156 & - & 120 & 197.4 & 140.9 \\
\hline
\end{tabular}

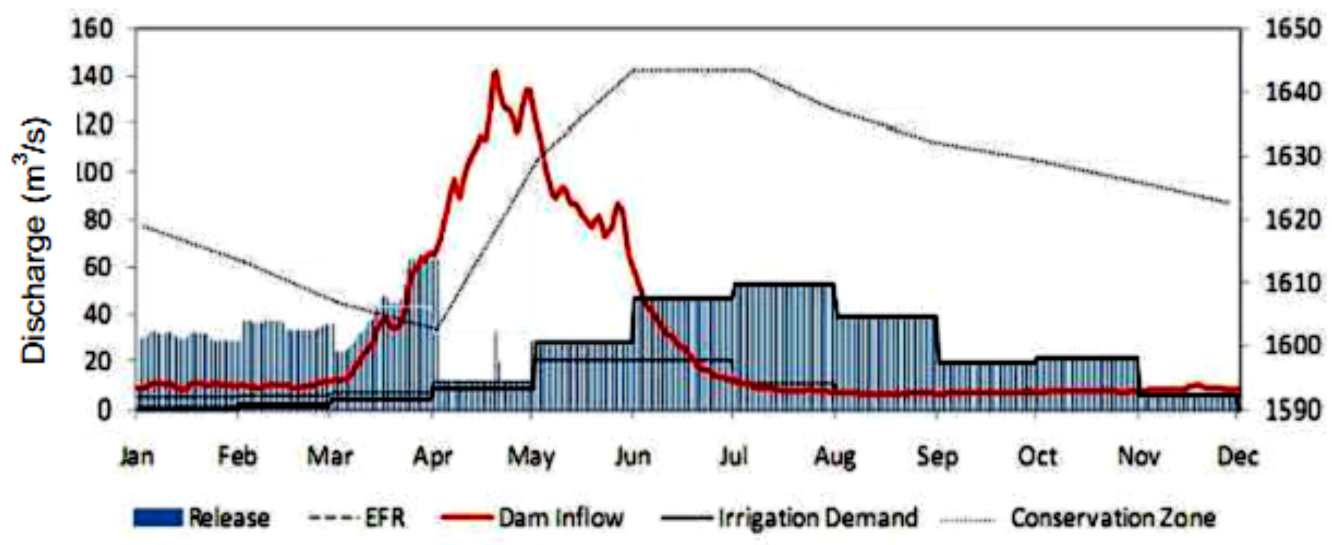

Figure 5. Proposed guide curve of conservation zone for reservoir operation. 
Adhikary et al., Simulating Impacts of EFR Consideration on Reservoir Operation Policy and Irrigation Management in the Hari Rod River basin, Afghanistan

\subsection{Improvement of Irrigation Efficiency (IE) for Minimizing Potential Impacts}

Improving the current irrigation practices could be another possible solution for minimizing the irrigation shortage. Before the conflict period, total cultivated area was about 97,000 ha, which has been drastically decreased to 42,141 ha. Thus, there is a potential scope of expanding the current irrigation scheme. Scenario II shows that there will be shortage of water in dry years for 74,859 ha irrigable areas if EFR demand is considered into reservoir operation policy. Therefore, improving IE can be a good option to mitigate this impact. For this, average IWR per ha was estimated to find total demand of future irrigable area. Table 4 depicts that improving only 5\% IE, there will not be any shortages for irrigation, hydropower and EFR demand. During dry season, total supply and demand from reservoir is simulated as $226.00 \mathrm{Mm}^{3}$ and $240.26 \mathrm{Mm}^{3}$. The demand is more than the supply which means that there is shortage in existing IWR having $35 \%$ IE. The result also shows that the irrigation demand is decreased approximately about $15 \mathrm{Mm}^{3}$ for improving IE only $5 \%$, and hence the supply is meeting the full demand. Besides, further options will be created for cultivating more irrigable area during wet years with the surplus water.

Table 4: Improving irrigation efficiency to satisfy irrigation demand of the whole cultivated area

\begin{tabular}{|c|c|c|c|c|c|}
\hline Description & Unit & Irr. Eff. (IE) & Wet Season & Dry Season & Total \\
\hline Total irrigation water supply (winter) & $\mathrm{Mm}^{3}$ & - & 361.01 & 226.00 & 587.01 \\
\hline Irr. Eff. increasing by $5 \%$ IWR (winter) & $\mathrm{Mm}^{3}$ & $40 \%$ & 317.24 & 225.09 & 542.33 \\
\hline Irr. Eff. increasing by $5 \%$ IWR (winter) & $\mathrm{Mm}^{3}$ & $45 \%$ & 309.59 & 221.09 & 530.68 \\
\hline Irr. Eff. increasing by $5 \%$ IWR (winter) & $\mathrm{Mm}^{3}$ & $50 \%$ & 303.11 & 211.54 & 514.65 \\
\hline
\end{tabular}

\section{CONCLUSIONS}

This study was an attempt to establish EFR in the Hari Rod River basin of Afghanistan using different wellknown hydrological and hydraulic methods. After estimating EFR, a reservoir simulation model was developed for the proposed reservoir (Salma dam reservoir) system applying HEC-ResSim model to estimate the impact of incorporating EFR into the reservoir operation policy as well as on the irrigation management. It was found that the hydrological based methods were suitable to establish EFR in the Hari Rod River basin of Afghanistan. Estimated EFR using IHA method considering RVA approach was preferred for simulating reservoir model, as it considers natural flow variability, magnitude, frequency and duration of flow during EFR estimation. The study concludes that there will be shortage of water during dry years if Salma dam reservoir operates for meeting all three demands such as irrigation, EFR and hydropower production. Impact of EFR consideration on the reservoir operation policy can be mitigated by applying the developed conservation zone for dry years. This can save about 2000 ha land that was supposed to be affected. The present study conclusively proves that only 5\% improvement in the existing IE can mitigate entire water shortage impact in the Hari Rod River basin of Afghanistan.

\section{ACKNOWLEDGEMENT}

The authors wish to thank "The Government of the Netherlands" for extending full financial support and "Asian Institute of Technology (AIT), Thailand" for providing the technical assistance to carry out this study.

\section{REFERENCES}

FAO (1999). Users' manual of CROPWAT for windows, version 7.0., Food and Agriculture Organization of United Nations, Rome, Italy.

Qureshi, A.S. (2002). Water resources management in Afghanistan: the issues and options, International Water Management Institute (IWMI) Working Paper No. 49, Colombo, Sri Lanka.

Smakhtin, V. and Anputhas, M. (2006). An assessment of environmental flow requirements of Indian River Basins, International Water Management Institute (IWMI) Research Report No. 107, Colombo, Sri Lanka.

Smakhtin, V., Revenga, C. and Döll, P. (2004). A pilot global assessment of environmental water requirements and scarcity, Water International, 29(3), 307-317.

Song, J.X., Xu, Z.X., Liu, C.M. and Li, H.E. (2007). Ecological and environmental in-stream flow requirements for the Wei River-the largest tributary of the Yellow river, Hydrological Processes, 21, 1066-1073.

Tharme, R.E. (2003). A global perspective on environmental flow assessment: emerging trends in the development and application of environmental flow methodologies for rivers, River Research and Applications, 19, 397-441. 